\title{
Baltic Ordovician compound sponges as erratics on Gotland (Sweden), in northern Germany and the eastern Netherlands
}

\section{F. Rhebergen}

Slenerbrink 178, NL- 7812 HJ Emmen, the Netherlands. Email: freek.rhebergen@planet.nl

Manuscript received: May 2007; accepted: November 2007

\begin{abstract}
Compound orchocladine sponges are unusual in the Early Palaeozoic. In Europe, silicified material of Late Ordovician age has hitherto been referred to as Aulocopium aurantium 0swald, 1847 and the invalid Aulocopium compositum Conwentz, 1905. An examination of new material has resulted in the recognition of a new genus, Hydraspongia, with two new species, H. polycephala and $H$. erecta, and a third new species, Perissocoelia megahabra, to which most specimens can now be assigned. These taxa form part of rich erratic sponge assemblages, which originate from unknown source areas in the Baltic, and have been collected in northern and western Europe from fluvial sandy deposits of the Eridanos River system, which drained the Baltic area from the Middle Miocene to Early Pleistocene.
\end{abstract}

Keywords: Baltica, erratics, new taxa, Ordovician, Porifera

\section{Introduction}

Compound orchocladine demosponges were uncommon during the Ordovician. Although digitate and dichotomously branching forms did occur, records of forms with clusters of oscular areas are few and far between. The oldest compound sponge species known to date is of Early Ordovician age from the Precordillera, Argentina (Carrera 2006). The taxa described below are of Late Ordovician age and are more or less coeval with those from the Malongulli Formation in New South Wales, Australia (Rigby \& Webby 1988). Comparable forms have been described from Silurian strata in Arctic Canada (Rigby \& Chatterton 1989) and from Permian deposits on Timor (Gerth 1927) and in Texas (Finks 1960).

Carrera \& Rigby (1999), in their study of the palaeobiogeography of Ordovician sponges, considered the erratic sponge assemblages from Baltica to be closely related to those from eastern Laurentia and assumed a strong faunal exchange between both cratons. They proposed a differentiation of Late Ordovician sponge faunas into two main associations: Atlantic faunas, including those from eastern Laurentia and Baltica, and Pacific ones, the latter subdivided into western Pacific faunas (New South Wales) and eastern Pacific faunas (western
North America and Asia). In this respect, it is remarkable that compound sponges occur in Baltica as well as in New South Wales, but are absent from eastern Laurentia, considering the similarity between the sponge assemblage of the latter and that from Baltica. Carrera \& Rigby (2004) documented the evolutionary development of Ordovician sponges and diversification patterns of the lithistid Orchocladina, and used these to discuss possible patterns of distribution. They suggested a migration from eastern Laurentia to Baltica and from Baltica to eastern Australia to have taken place during the Late Ordovician (Carrera \& Rigby 2004, p. 109). However, the composition of sponge faunas from Baltica and eastern Laurentia differs considerably from that of the Australian assemblages, the latter comprising numerous endemic species (Rigby \& Webby 1988).

In European literature, compound sponges have only briefly been mentioned so far, e.g. by Conwentz (1905). Taxa described below are part of varied assemblages, known exclusively as erratics from unknown source areas in Baltica (Von Hacht \& Rhebergen 1997). They were transported by the Eridanos River system, which drained the Baltic Basin and areas farther to the north and northeast, from the Middle Miocene to the Early Pleistocene (Bijlsma 1981; Overeem et al. 2001). Most of the available material was collected from fluvial sandy deposits on 
the island of Sylt (northern Germany), mainly of Pliocene age; in the eastern Netherlands and adjacent areas in Germany (for short: the WWW area, named after the villages of Westerhaar, Wilsum and Wielen), of Early Pleistocene date and on Gotland (Sweden), the latter reworked by Weichselian glaciers (Fig. 1).

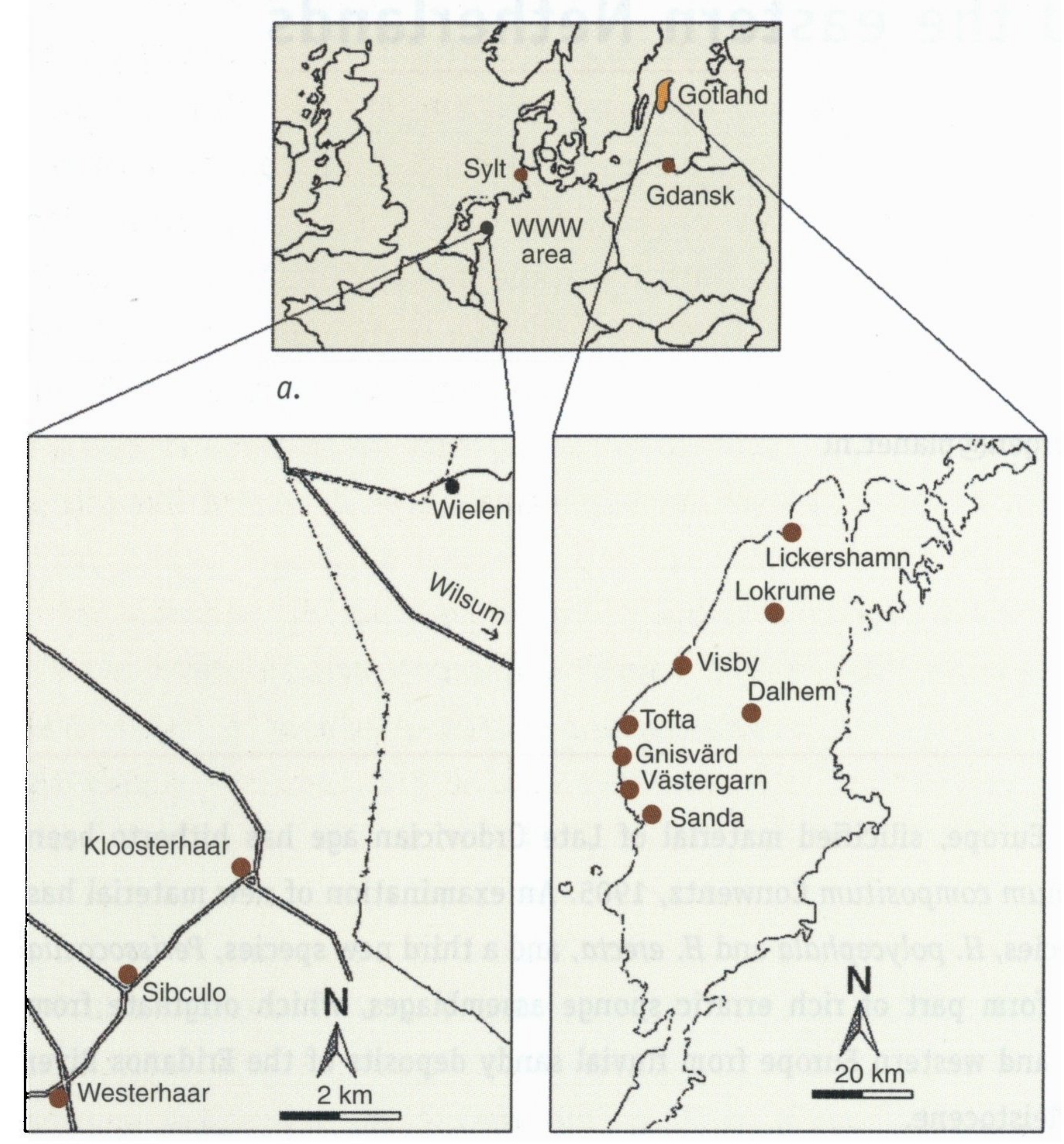

$b$.

c.

Fig. 1. Map of northern Europe (a) with the geographical position of areas from where most of the material studied originated; $b$. The DutchGerman border area, for short:WWW area, after the villages of Westerhaar, Wilsum and Wielen; c. Gotland (Sweden).

Aulocopium aurantium accounts for 40 and 55\%, respectively, in two assemblages distinguished by differences in composition and assumed provenance (Von Hacht \& Rhebergen 1997; Rhebergen et al. 2001). This species displays such a wide range of body forms and dimensions, that numerous specimens have been assigned erroneously to it, inclusive of compound forms. Other specimens have often been assigned to Aulocopium compositum Conwentz (1905), based only on the illustration of a multiheaded specimen (see Fig. 2), without any description added (see below). The present reexamination has resulted in the recognition of a new genus, Hydraspongia, with two new species, $H$. polycephala and $H$. erecta, and a third new species of the genus Perissocoelia, $P$. megahabra, to accommodate most compound sponges.

\section{Abbreviations}

To denote the repositories of material referred to in the text, the following abbreviations are used:

LMG Länsmuseet på Gotland (County Museum of Gotland), Visby (Sweden);
EZ Ecodrome Park Zwolle, Zwolle (the Netherlands);

NME Natuurmuseum Enschede, Enschede (the Netherlands);

NRM Naturhistoriska Riksmuseet (Swedish Museum of Natural History), Stockholm;

RGM Nationaal Natuurhistorisch Museum, Leiden (the Netherlands);

SGU Geological Survey of Sweden, Uppsala (Sweden).

\section{Material, methods and preservation}

About seventy specimens of compound sponges have been examined. Material from Gotland (Sweden) is housed in the NRM, LMG and SGU collections, and in the Leipnitz Collection (Uelzen, Germany). The majority of specimens from the WWW area are deposited in the RGM, NME and EZ collections, as well as in private collections. Specimens from Sylt are in the Von Hacht Collection and at the Archiv für Geschiebekunde, Geologisch-Paläontologisches Institut und Museum der Universität Hamburg (Germany). Type material selected from private collections has now been transferred to museums.

Some specimens were cut axially and their surfaces polished for microscopic examination of internal structures, which only on very few occasions proved successful. Generally, skeletal structure was obliterated by in-depth silicification and replacement, usually by opaque chalcedony. Thus, in general, measurement of spicule size proved impossible. Occasionally, moulds of dissolved desmas are pyrite-filled or contain a mealy, siliceous powder that make them visible in translucent chalcedony, especially in distal zones.

\section{Systematic palaeontology}

Class Demospongea Sollas, 1875

Order Lithistida Schmidt, 1870

Suborder Orchocladina Rauff, 1894

Family Streptosolenidae Johns, 1994

\section{Genus Hydraspongia gen. nov.}

\section{Type species}

Hydraspongia polycephala sp. nov.

\section{Etymology}

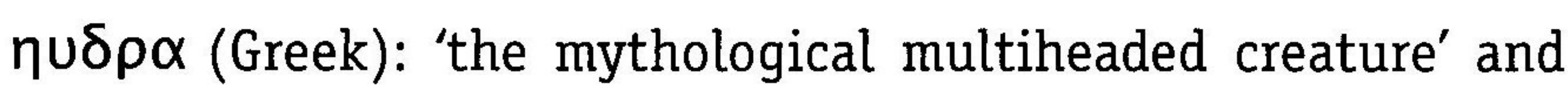
spongia: (Latin): sponge.

\section{Diagnosis}

Massive, obconical to cylindrical, stalked, compound sponge, varying in size from moderately small to huge, with dense, basic dermal layer. Upper part composed of a variable number 
of oscular heads. Discontinuous growth stages demonstrated by laterally alternating zones with and without dermal layers and by frequent overgrowths of previously formed oscular heads. Excurrent system in each oscular head composed of axial canals, emptying into the base of the spongocoel. $S$ shaped canals radiate inwards from distal part of an oscular system to its axis, emptying at sharp angles into axial canals, or bending upwards and continuing as axial canals. Smaller canals, parallel to the skeletal structure, radiating upwards and outwards from the median plane of the sponge body. Anthaspidellid skeleton composed of discontinuous, stacked series of trabs of predominantly dendroclones and chiastoclones, but rhizoclones do also occur. Position of skeletal radiante at the base.

\section{Discussion}

Individuality in sponges is less distinct than in true Metazoa and this may cause problems in distinguishing an individual sponge from a colony (Reid 2003, p. 11). Carrera (2006) summarised such issues as individuality, compound growth forms, clones, colonies and budding, which have been continuously discussed for more than a century, (see e.g. Bergquist (1978), Hartman \& Reiswig (1973) and Wood et al. (1992). Compound sponges discussed below are herein defined as individuals, with a single base, a continuous skeletal structure in common, and development of two or more oscular centres.

Rigby (2004) included in the Orchocladina, among others:

- Anthaspidellidae Ulrich in Miller, 1889, including taxa with a skeleton composed predominantly of I-shaped dendroclones;

- Streptosolenidae Johns, 1994, including taxa with a more irregular skeleton of predominantly Y- and H-shaped dendroclones, and comparatively more chiastoclones and rhizoclones;

- Chiastoclonellidae Rauff, 1894, including taxa with or without a poorly developed system of trabs and with a skeleton composed predominantly of chiastoclones.

Mehl-Janussen (1999) considered the 'Streptosolenidae' to be paraphyletic and proposed the name to be used in a descriptive sense only. In her opinion, all sponges with chiastoclones should be assigned to the Chiastoclonellidae. In the present paper, the classification outlined by Rigby (2004) is followed. Skeletal structures will be defined by the generally used term 'anthaspidellid', rather than the uncommon 'streptosolenid'.

The first report of an Ordovician compound sponge from Europe was that by Conwentz (1905, pl. 3, fig. 4), who illustrated a specimen from Schönwarling, district of Danziger Höhe, as Aulocopium compositum (Fig. 2), but provided no description. It was originally housed in the 'Westpreussisches Provinzial Museum' at Danzig, now Gdańsk, northern Poland, but the specimen could not be traced there. Most probably, it got lost in 1944.

There are only few references to Early Palaeozoic compound sponges from Baltica, e.g. by Krul (1954), Van Kempen (1982) and Von Hacht $(1982,1990)$, who all assigned them to the genus Aulocopium 0swald, 1847. Rhebergen et al. (2001) did not agree with such an assignment and rather referred them in open nomenclature to Perissocoelia Rigby \& Webby, 1988.

Rigby \& Webby (1988), in their description of a sponge assemblage from the Upper Ordovician Malongulli Formation, New South Wales (Australia), erected the genus Perissocoelia, which is characterised by a number of osculi distributed over the upper and lateral surfaces. Rigby \& Chatterton (1989) and Carrera (2006) erected also new taxa of compound sponges from Arctic Canada and Argentina, respectively, which will be discussed below.

Aulocopium and Hydraspongia gen. nov. have an obconical stalked base and a wrinkled dermal layer in common. The former has a single oscular centre with a deep spongocoel, continued by a cluster of vertical canals, reaching nearly the base of the sponge. Stacked series of well-developed, convexly bent exhalant canals run from near the lateral wall to the centre. This structure differs from that seen in $H$. erecta sp. nov., which, as a rule, has conspicuous S-shaped excurrent canals, emptying at acute angles into the axial canals. In addition, canals of $A$. aurantium are so long and wide, that they drain distal areas situated at a considerable distance from the central spongocoel, and do not form lateral oscular centres.

Multispongia Carrera, 2006 is a compound lamellar-shaped sponge from Lower Ordovician deposits in the Argentine Precordillera. Coalescent interconnected spongocoels form a thick, bulbous laminated body. Associated spongocoels are deep, reaching almost the base of the sponge. The skeletal structure is composed mainly of trabs, in which vertical, fused coring monaxons are the main elements. They are interconnected by I-shaped dendroclones in some places only. Thus, the genus differs markedly from Hydraspongia gen. nov.

Phacellopegma Gerth, 1927 is a Permian compound sponge from Timor, which was redescribed by Finks (1960). It is a massive, sub-hemispherical sponge with a surface covered with anastomosing, deep grooves on the surface, into which circular excurrent canals open.

Multistella Finks, 1960 is a Permian sub-hemispherical, compound sponge from Texas, with a layered growth form, overlapping former layers. The surface has small, astrorhizelike oscular centres, only 1 - $2 \mathrm{~mm}$ deep, into which small superficial canals empty.

Perissocoelia Rigby \& Webby, 1988 comprises compound sponges from the Malongulli Formation (Upper Ordovician) in New South Wales. It is a relatively small sponge, the largest specimen measuring $40-45 \mathrm{~mm}$ across and $25-30 \mathrm{~mm}$ in height. It has a large number of oscular pits, measuring $2-5 \mathrm{~mm}$ 
across, and $10-18 \mathrm{~mm}$ apart. Hydraspongia gen. nov. is considerably larger, developing bulbous oscular heads, which are $40-60 \mathrm{~mm}$ in diameter, with an average distance of $45 \mathrm{~mm}$ between the spongocoels of adjacent heads (see below). In addition, Hydraspongia gen. nov. shows successive growth stages, in contrast to Perissocoelia.

Anthaspidella Ulrich \& Everett in Miller, 1889 includes several species, all of which usually have a concave, saucer-like top, in which a number of oscular centres occur. All species have a stalked basal part, but lack a dense basic, as well as lateral alternating zones of dermal layer. Thus, the genus differs principally from Hydraspongia gen. nov.

Finally, De Freytas (1991, p. 2057, fig. 6M) illustrated a poorly preserved compound, probably anthaspidellid, sponge with four osculi from the Silurian (Ludlow) Cape Phillips Formation on Cornwallis Island (Arctic Canada), showing a certain superficial similarity to Hydraspongia.

\section{Hydraspongia polycephala sp. nov.}

Figures $2-7$.

\section{Etymology}

по $\lambda$ U_кÉ $\varphi \alpha \lambda$ оS (Greek): poly headed, referring to the variable number of bulbous oscular heads.

Synonymy

1905. Aulocopium compositum Conwentz, p. 33, pl. 3.

1954. Aulocopium compositum Conwentz, 1905 - Krul, pp. 33-34, 36-37, figs. 11-12.

1982. Aulocopium aurantium 0swald, 1847 - Von Hacht, pp. 24-30; figs. 1-4.

1982. Aulocopium aurantium 0swald, 1847 - Van Kempen, pp. 79-81.

1988. Aulocopium aurantium 0swald, 1847 - Rigby \& Webby, p. 32.

1990. Aulocopium compositum Conwentz, 1905 - Von Hacht, pp. 111-114, pls. 3-4.

2000. Aulocopium compositum Conwentz, 1905 - Eliason, p. 58, fig. 1.

2001. Perissocoelia sp. Rigby \& Webby, 1988 - Rhebergen et al., pp. 4, 62, 63, pl. 5.

2002. Perissocoelia sp. Rigby \& Webby, 1988 - Pisera, p. 390, fig. 4.

\section{Type material}

\section{Holotype}

LMG G34, erratic from Botvide, Kyrkbyhage, Sanda, Gotland (Sweden). Coordinates: N 57 $25^{\prime}$; E $18^{\circ} 13^{\prime}$.

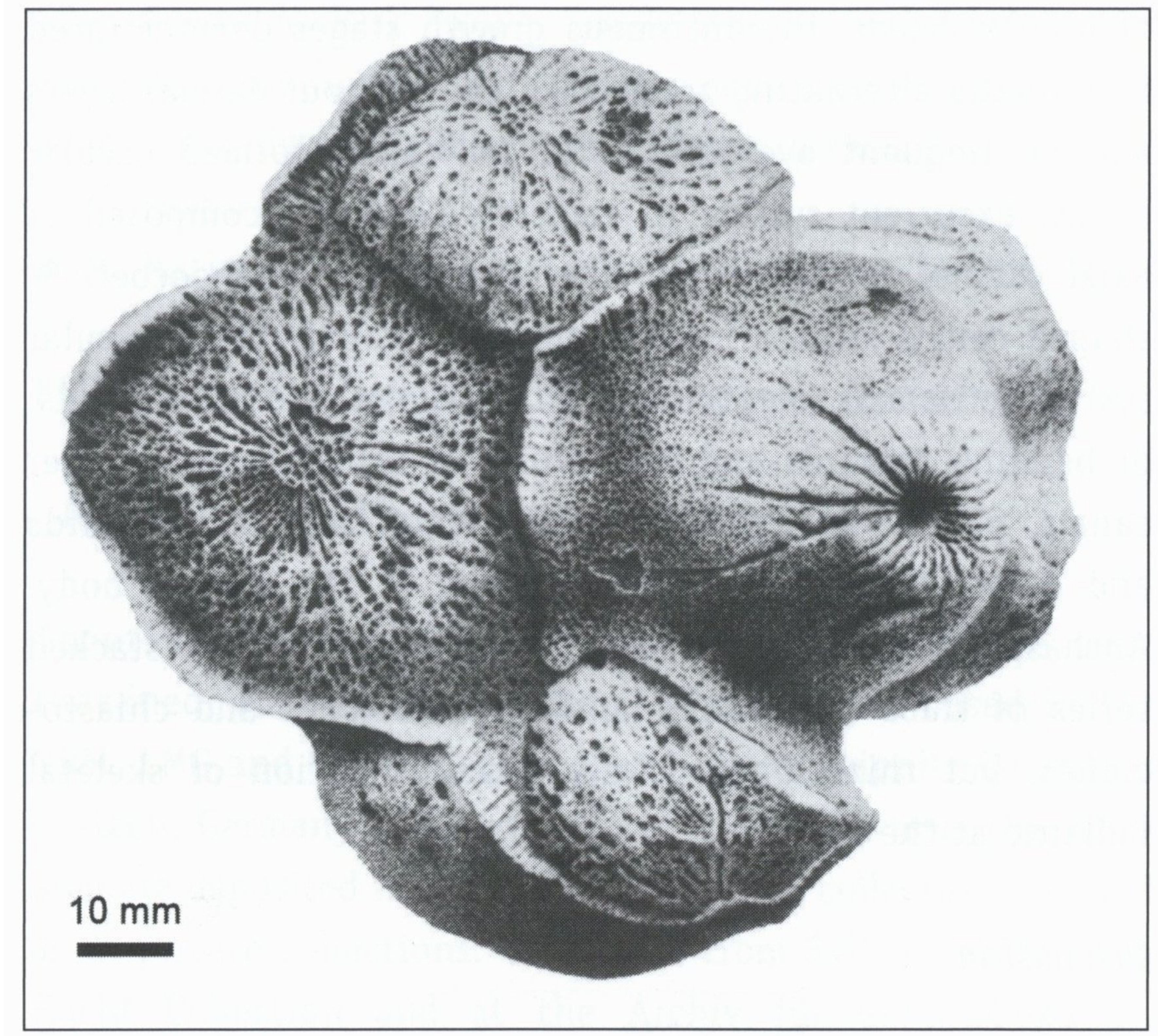

Fig. 2. Hydraspongia polycephala gen. et sp. nov. The oldest picture known of an erratic Ordovician compound sponge from Schönwarling in the Danzig area, now Gdańsk (Poland). It was illustrated by Conwentz (1905), who referred to it as Aulocopium compositum. Its present whereabouts are unknown. Most probably it got lost in 1944.

\section{Paratypes}

NRM Sp1864, erratic from Sanda, Gotland (Sweden); EZ Z.18271, erratic from Westerhaar (the Netherlands); NRM Sp1860, erratic from Dalhem, Gotland (Sweden).

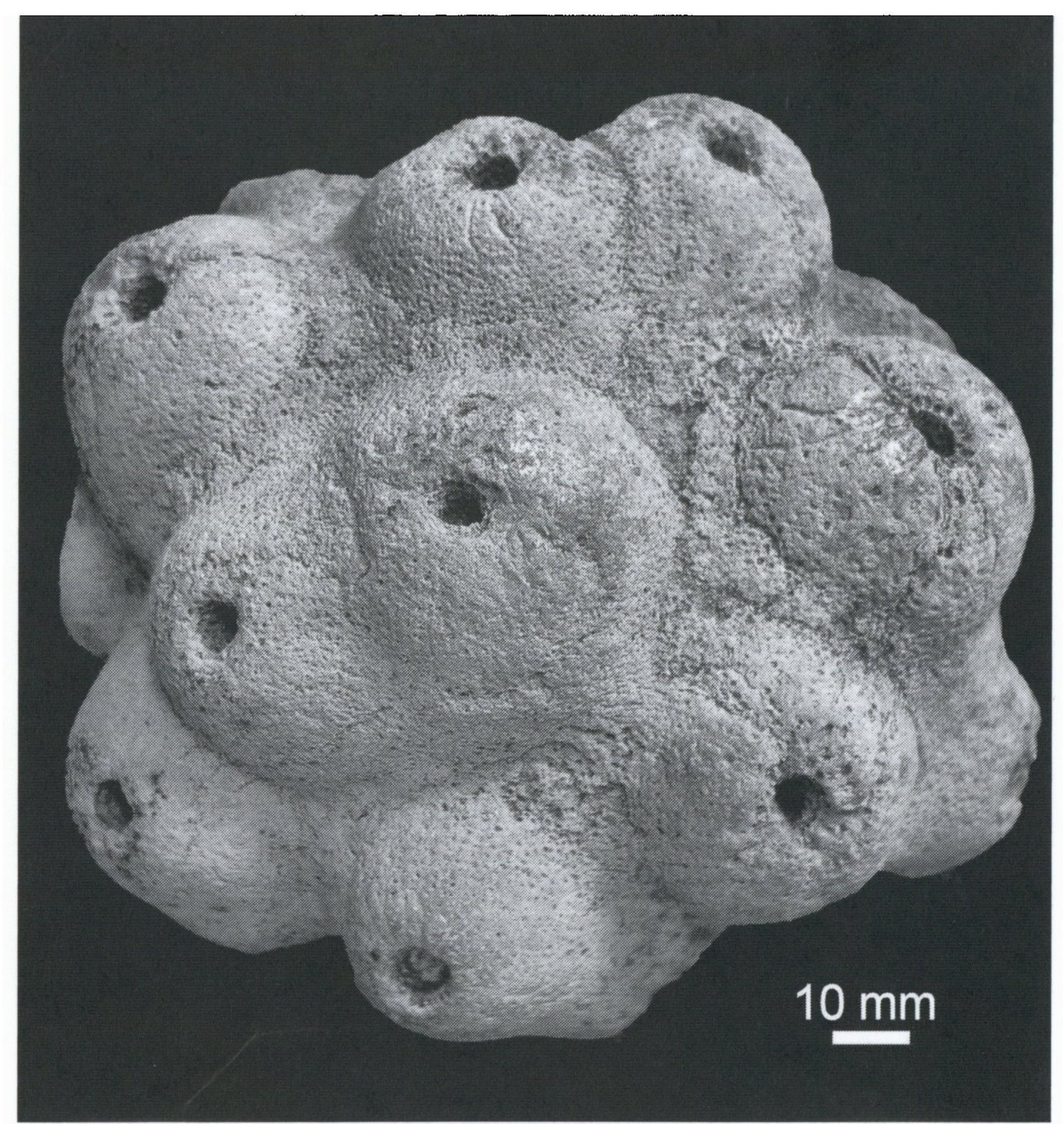

Fig. 3. Hydraspongia polycephala gen. et sp. nov. Holotype (LMG G34). Erratic from Botvide, Kyrkbyhage, Sanda, Gotland (Sweden). Oblique view of upper surface of a nearly complete specimen. 


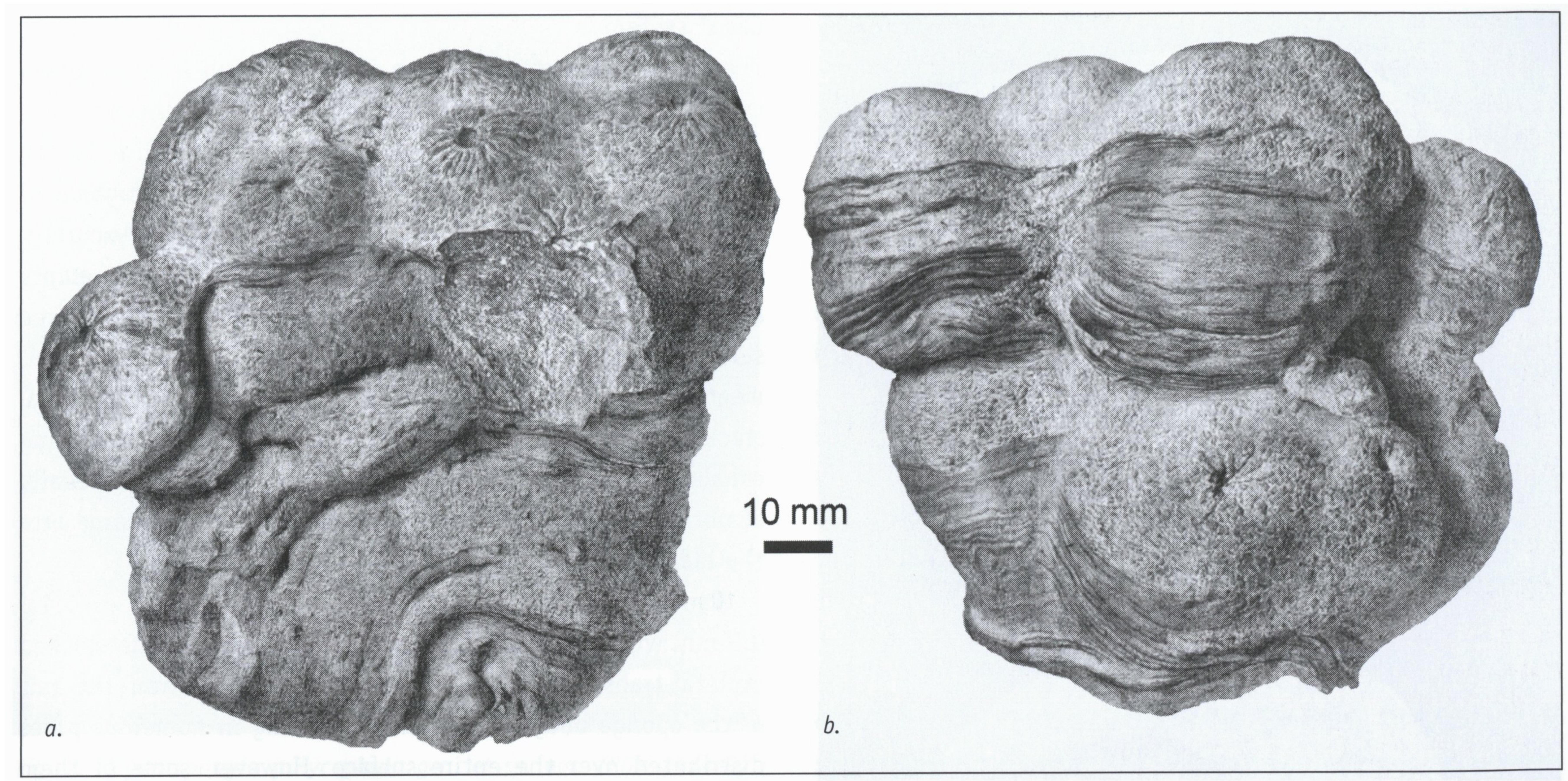

Fig. 4. Hydraspongia polycephala gen. et sp. nov. Paratype (NRM Sp1864). Erratic from Sanda, Gotland (Sweden). Unpublished pictures by Liljevall drawn near the end of the nineteenth century; a. Successive growth stages in the lower part are indicated by conspicuous rims of dermal layer; b. Ramification of a lateral oscular head which was not subsequently overgrown. The upper part illustrates lateral view of oscular heads which developed at a latter growth stage.

\section{Other material}

NRM Sp1118, NRM Sp1467, NRM Sp1863, NRM Sp4532, RGM 211489, SGU 9406, LMG G 864, NME 6300.01869 and ca forty specimens in private collections.

\section{Diagnosis}

Massive, obconical, subspherical to elliptical, compound sponge, varying in size from moderately small to huge, with dense, basic dermal layer. Laterally alternating zones both with and without dense dermal layer. Convex upper part usually composed of bulbous oscular centres. Frequent overgrowths of previously formed oscular heads by new heads marked usually by conspicuous, occasionally overlapping margins of dense layer. Within each oscular system, axial canals empty into the base of the spongocoel. Radiating arcuate canals in interior stacked, extending from the margins of a bulbous head and emptying into side of the spongocoel. Canals in lower parts of the bulbous head sloping steeply downwards and outwards, distally gradually merging to subparallel to the surface. Smaller convex canals parallel to the anthaspidellid skeletal structure, flaring upwards and outwards from median axis of the sponge body to the surface.

\section{Description}

\section{Body form}

The body form of Hydraspongia polycephala gen. et sp. nov. varies considerably. Most specimens are huge and massive, usually with two or three recognisable growth stages (see below). NRM Sp4532, the largest specimen known, is incomplete, yet measures $170 \mathrm{~mm}$ in length and $130 \mathrm{~mm}$ in height.

LMG G34, the holotype, is a near-complete specimen, 134 $\mathrm{mm}$ long, $120 \mathrm{~mm}$ wide and $82 \mathrm{~mm}$ high (Fig. 3). The base is covered by a dense, irregularly wrinkled dermal layer, part of which is worn in the centre. The upper part consists of ten regularly sub-hemispherical, bulbous heads. The heads are 32$62 \mathrm{~mm}$ (average $43 \mathrm{~mm}$ ) across and $30-40 \mathrm{~mm}$ (average $35 \mathrm{~mm}$ ) in height. At the transition from the base to the upper part, four additional bulbous heads are broken off, showing skeletal structures. One of the fractures is covered by a thin, convex, dense layer, indicating the transition from the massive sponge body to the base of the oscular head. Two oval heads bifurcate, each with two spongocoels. Two other oscular heads have outgrowths at their bases, where one and two small spongocoels, respectively, indicate the growth of new oscular centres. Thus, the specimen has eighteen oscular centres in total. Distances between osculi are fairly constant, varying between 30 and $50 \mathrm{~mm}$ (average $41 \mathrm{~mm}$ ).

The ontogenetic development is well demonstrated by NRM Sp1864 (Fig. 4). The small irregular, conical base is covered by a dense, wrinkled dermal layer, ending abruptly in a distinct rim, ca $20 \mathrm{~mm}$ from the initial point of growth. This rim forms the base of three oscular heads, which developed obliquely upwards (Fig. 4a). Tops of two heads were covered by a welldefined zone of dermal layer, on which four or five new oscular heads developed. Most of these heads bifurcated, forming two spongocoels, each about $25 \mathrm{~mm}$ apart. The third 


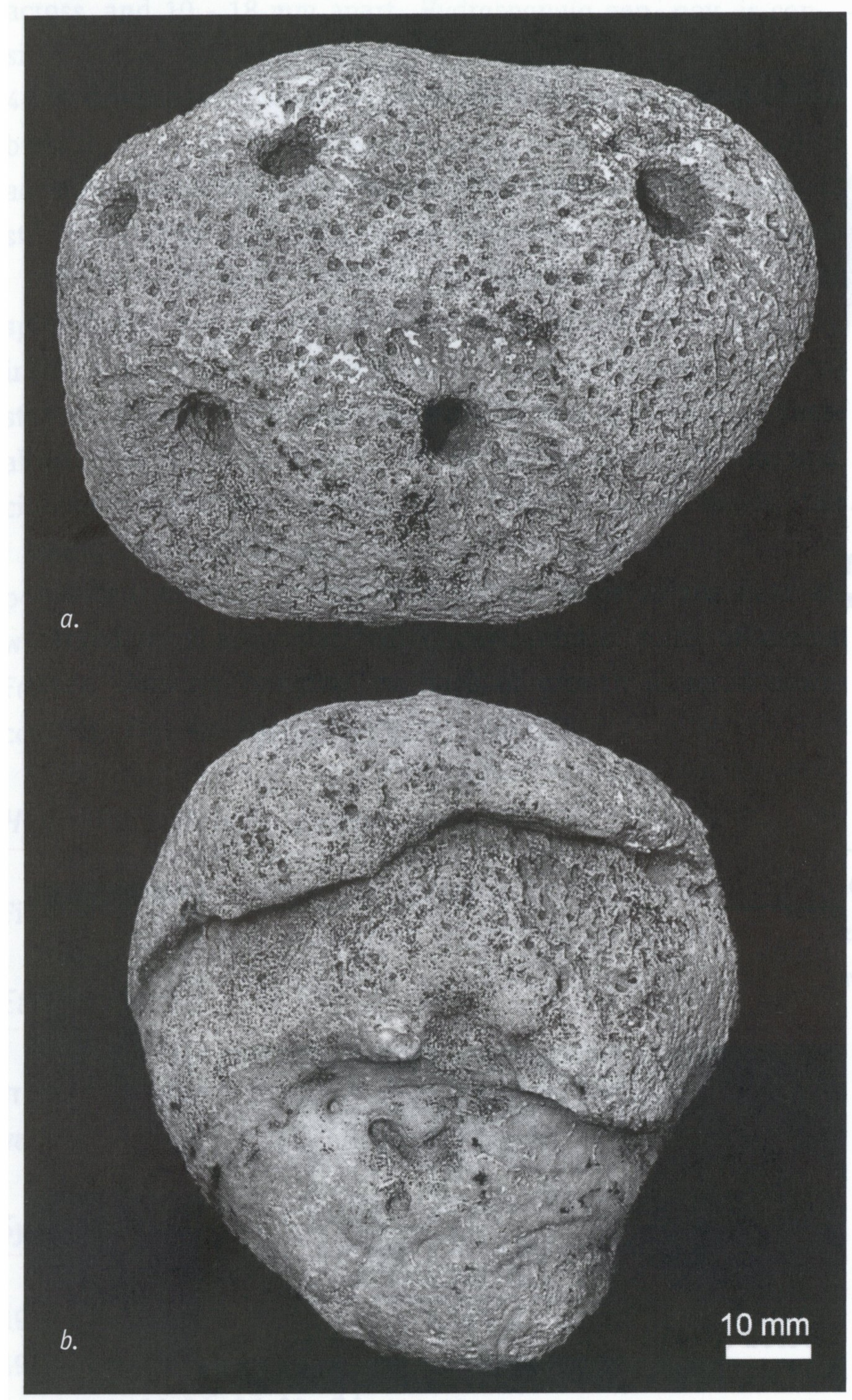

Fig. 5. Hydraspongia polycephala gen. et sp. nov. Paratype (NRM Sp1860). Erratic from Dalhem, Gotland (Sweden); a. Top view of the crest; $b$. Successive growth stages distinctly marked by overlapping zones of dermal layer. Superficial excurrent canals in the central zone run to an oscular pit of a head now hidden.

one developed into a bulbous head, ca $50 \mathrm{~mm}$ wide and $30 \mathrm{~mm}$ high, upon which a new oscular system grew (Fig. 4b). A similar development is seen in NRM Sp1860 (Fig. 5) and EZ Z.18271 (Fig. 6). In the latter specimen, the initial bulbous oscular head was overgrown by three others, two of which developed on top of the first, the third slightly obliquely. These three heads are separated distinctly from the first one by a circumferential zone of dense dermal layer. One of these heads grew obliquely upwards, measuring 65 by $40 \mathrm{~mm}$, and, in turn, bifurcated again. Upon the two other heads, two spongocoels developed.

Often, transitions from one growth stage to the next are marked by sharply defined, circumferential folds of dermal layer, showing 'hanging' overlaps of growth directed downwards (Figs 4a, 5b).

\section{Canal system}

The aquiferous systems in each of the heads of $H$. polycephala gen. et sp. nov. are identical. A bundle of six to eight excurrent canals empty into the base of a spongocoel, normal to the surface of the head. In cross section, they are pentagonal or hexagonal and measure $0.6-0.7 \mathrm{~mm}$ across. Radiating excurrent canals, ca $20-30 \mathrm{~mm}$ long and $0.5-0.6 \mathrm{~mm}$ in diameter, empty at low angles into the lower part of the spongocoel. Stacked series of radiating canals merge gradually to subhorizontal, meeting the side of the spongocoel at right angles. Superficial stacked series of 12 - 18 irregular, slightly winding, radiating canals, empty into the upper side of the spongocoel, usually at obtuse angles. Other small superficial canals discharge into the radiating canals.

Another system of canals is composed of small, ca 0.4 $0.5 \mathrm{~mm}$ wide, circular canals arranged parallel to the stacked skeletal trabs. They flare upwards and outwards from the axis of the sponge body to the surface, ending in numerous pores distributed over the entire surface. However, some of them end bluntly against distal zones covered with a dermal layer, which is considered to be impervious (see Rigby \& Webby 1988).

\section{Skeleton}

The basic dermal layer in sponges of comparable taxa, such as Aulocopium, is composed of a dense mesh of predominantly chiastoclones and small, irregular dendroclones (Van Kempen 1983). Dermal layers which developed in lateral zones usually are thinner and smoother than those at the base, and show pores, often forming the centre of a small tubercle. The dense layer is not exclusively dermal, but formed internally as well. At the base of a (broken) bulbous head some specimens show an internal diaphragm-like continuation of the dermal layer. A relatively large number of oscular heads have broken off at nearly identical positions. In RGM 211489 (Fig. 7), eight of ten heads are broken. Probably, the layer formed a weak plane.

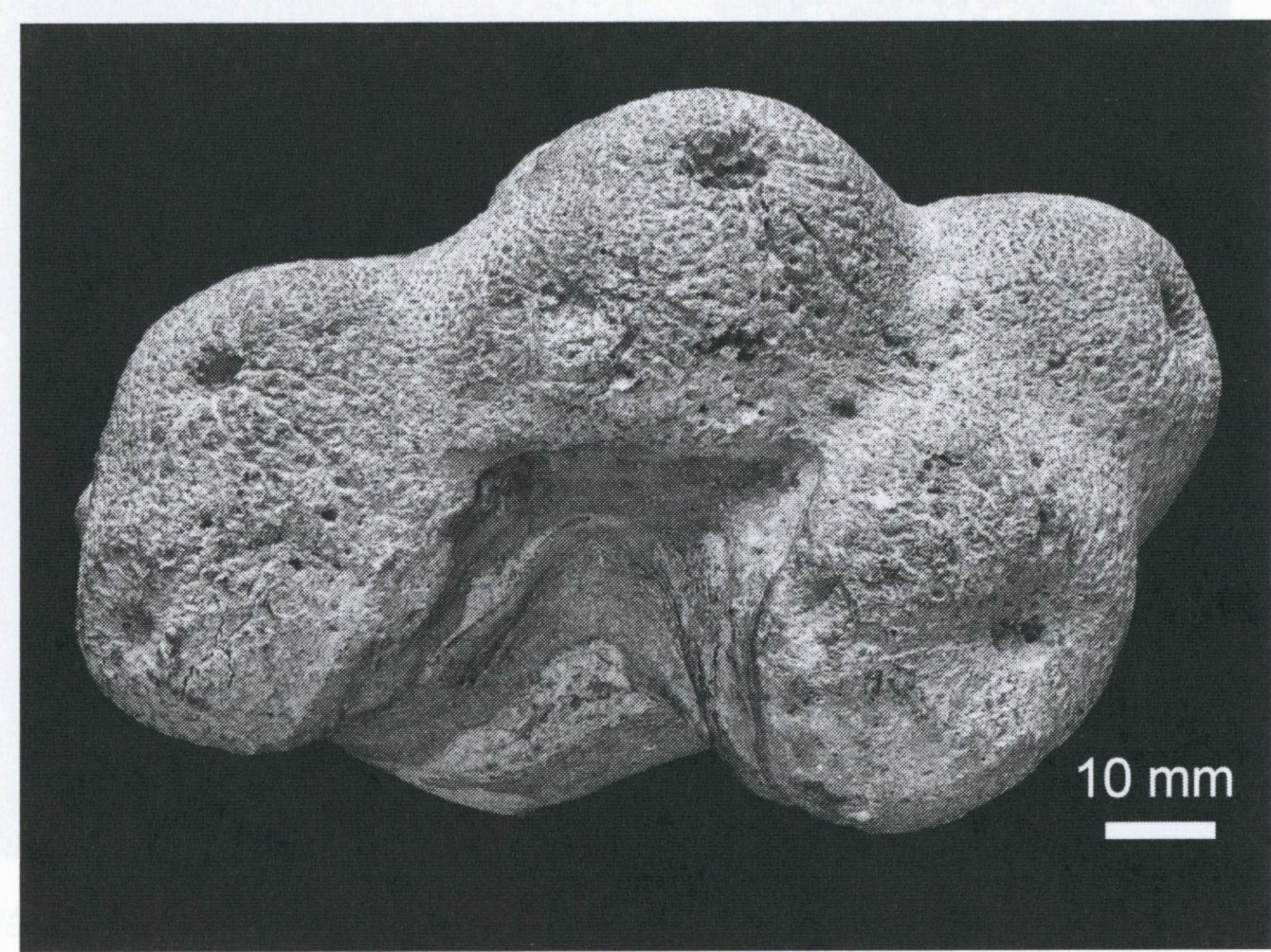

Fig. 6. Hydraspongia polycephala gen. et sp. nov. Paratype (EZ Z.18271). Erratic from Westerhaar (the Netherlands). Oblique top view, showing ramification of oscular heads at different stages of development. 


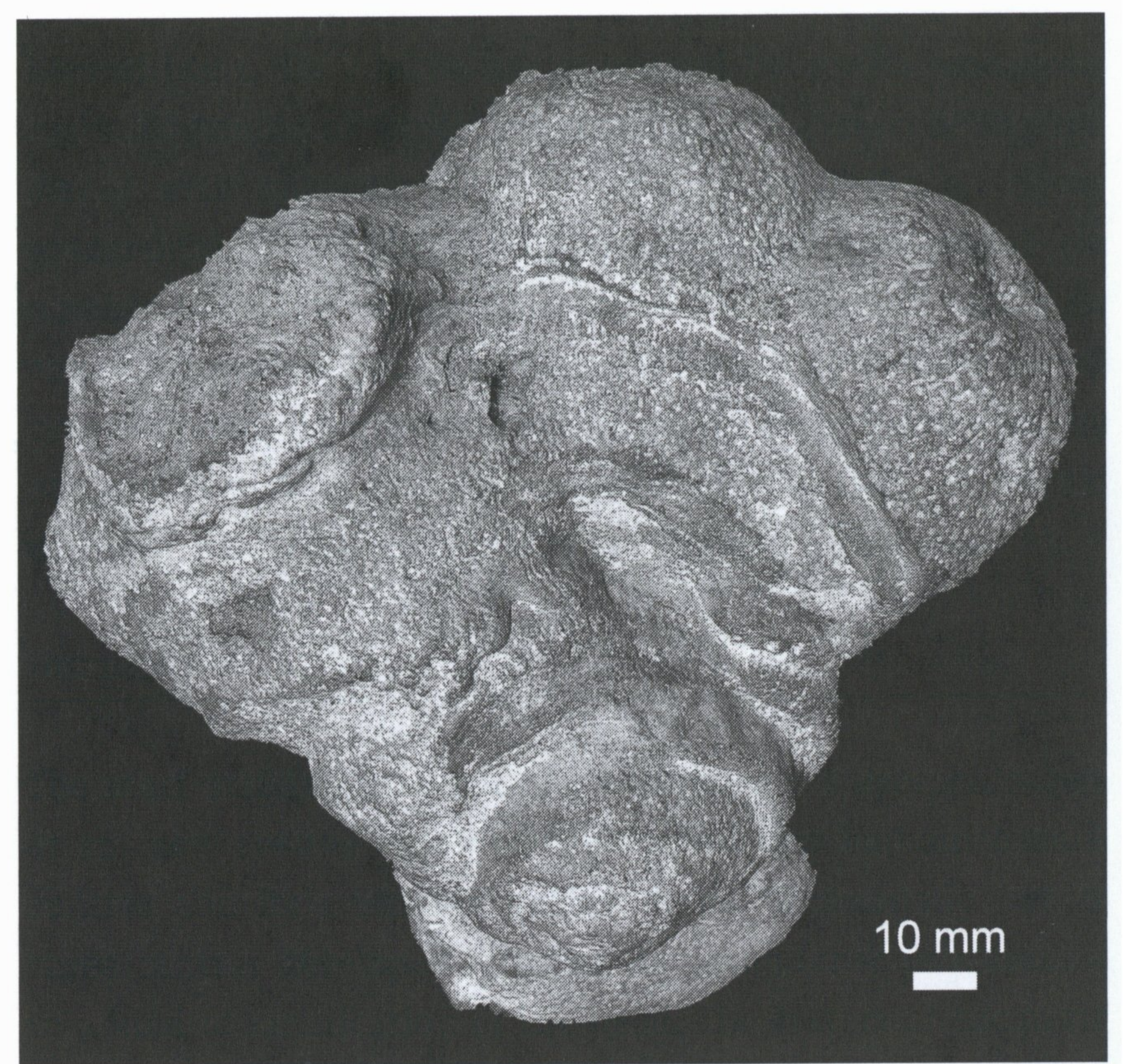

Fig. 7. Hydraspongia polycephala gen. et sp. nov. (RGM 211489). Erratic from Braderup, Sylt (Germany). Lateral view, demonstrating successive growth stages, marked by zones of dense dermal layer. Note the single oscular head at the base. The crest comprises ten oscular heads, eight of which are broken off, demonstrating the internal structures of the aquiferous system.

The main skeletal structure is anthaspidellid. Dominant skeletal elements are dendroclones usually arranged in regularly stacked, ladder-like series of trabs. They flare upwards and outwards continuously from the median centre of the sponge body to the outer wall, where they meet the surface under an angle of approximately $60^{\circ}$, but in areas with lateral outgrowth they meet at an angle of $90^{\circ}$ or, bending downwards, even at an angle of $150^{\circ}$. Within the stacked series, dendroclones are arranged normally or obliquely to the trab, thus forming the rungs of trabs. Zygomes of adjacent dendroclones are not fused, but firmly connected to each other (zygosis), thus forming the bars of trabs. They often are supported by coring monaxons, casts or moulds of which are occasionally observed. Dendroclones with relatively short Y-shaped and X-shaped clones predominate. The number of chiastoclones may equal the number of dendroclones in choasomal parts. Walls of canals are composed predominantly of strongly bent dendroclones, sometimes in connection with rhizoclones. The regular arrangement of trabs contrasts with the irregular arrangement of desmas within a trab. This feature is typical of the Streptosolenidae.

\section{Discussion}

The most striking features of Hydraspongia polycephala gen. et sp. nov. are the continuously formed new bulbous oscular centres and its multiplex growth form. 0ccasionally two or three centres developed more or less simultaneously, leading to a kind of ramification of the head. The system of excurrent canals in a bulbous head is independent of that in the underlying head. Usually, the spongocoel of an older head was overgrown. In contrast, when the spongocoel of the latter was uncovered, this older head developed continuously (Fig. 4b). These stages of discontinuous growth are also reflected in the zones of the dermal layer. Laterally, the sponge body is constricted, usually circumferentially, at the base of a zone with dense dermal layer. Both vertical and radial excurrent canals in each of the oscular heads do not run and discharge into the same direction as those in underlying heads. Thus, each oscular head has to be considered an independent unit, succeeding the previous generation. Damaged specimens confirm this observation, since no sponge body shows a continuous system of excurrent canals running from the base to the top of the sponge body. In contrast, axial cuts demonstrate a continuous growth of the anthaspidellid skeleton of stacked ladder-like series of dendroclones, radiating regularly upwards and outwards from the median axis to the sides. They show the sponge to be a single individual, rather than an aggregate or clonal organism.

Perissocoelia habra Rigby \& Webby, 1988 is a relatively small sponge from the Upper Ordovician of New South Wales. It differs from $H$. polycephala sp. nov. in being smaller and in lacking bulbous oscular heads and multiplex growth form.

Rare twin or triplet forms of Aulocopium aurantium 0swald, 1847 have no bulbous lateral heads either, nor do they possess internal diaphragm-like zones, or distinct growth stages.

\section{Hydraspongia erecta sp. nov.}

Figures $8-11$.

\section{Etymology}

Erectus (Latin): straight, erect, in allusion to the erect, cylindrical body shape.

\section{Synonymy}

1982. Aulocopium aurantium 0swald, 1847 - Von Hacht, pp. 26-27, fig. 2.

\section{Type material}

\section{Holotype}

LMG G863, erratic from unknown locality on Gotland (Sweden).

\section{Paratypes}

NME 6300.02115, erratic from Albergen (the Netherlands), RGM 211490, erratic from Wilsum (Germany), RGM 211491, erratic from Braderup, Sylt (Germany). 


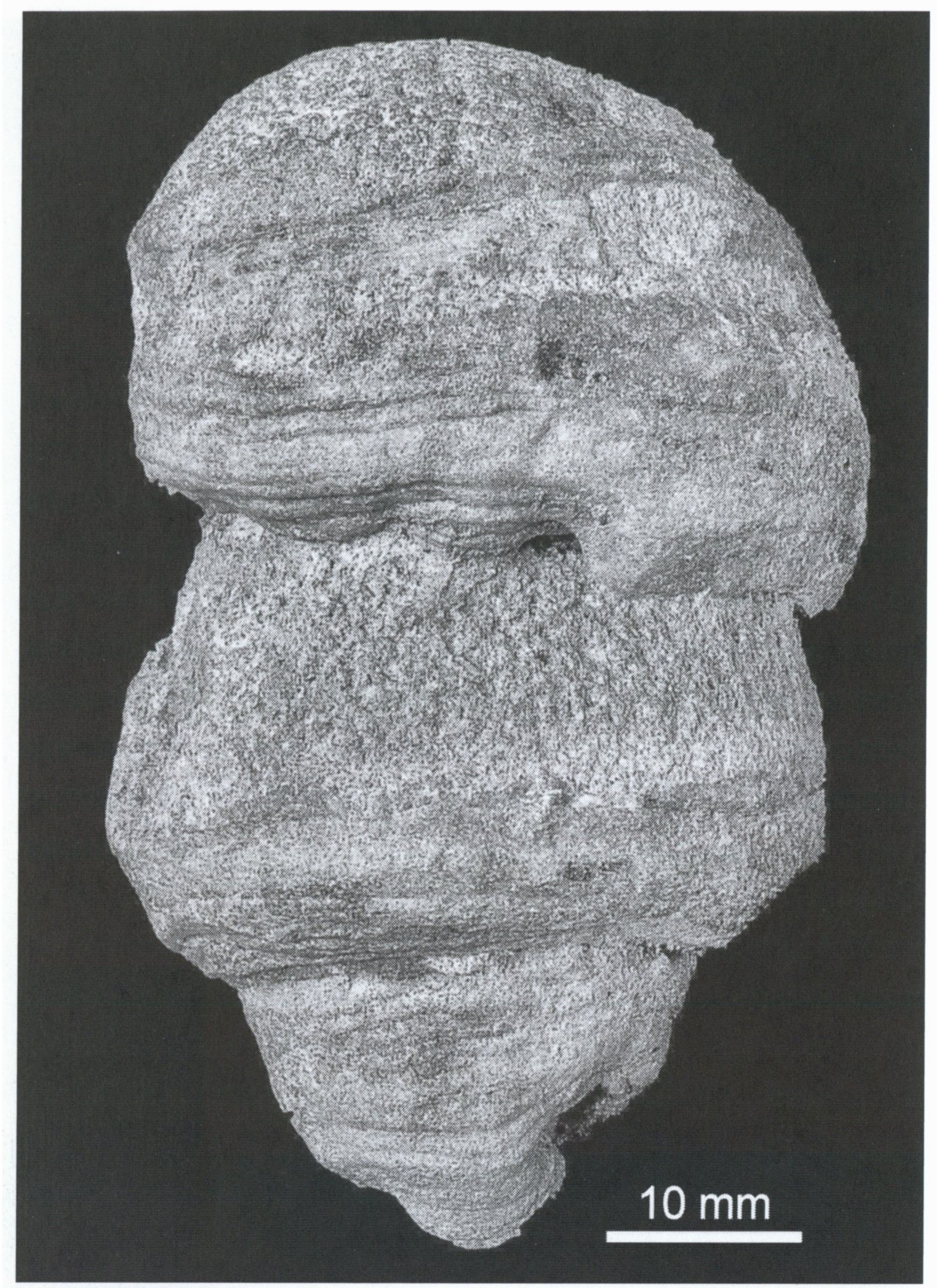

Fig. 8. Hydraspongia erecta gen. et sp. nov. (LMG G863). Holotype. Erratic from unknown locality on Gotland (Sweden). Lateral view. Sponge body composed of vertically stacked oscular heads, separated by sharply defined repetitive zones of dermal layer. Excurrent canals in the central part do not run towards the spongocoel of the upper head, but into a different direction, towards a spongocoel overgrown by the upper part.

\section{Other material}

RGM 211492 and ca twenty specimens in private collections.

\section{Diagnosis}

Cylindrical compound sponge of moderate to huge size. Stalked base with dense, dermal layer. Laterally, circumferential zones of dense dermal layer, sometimes extending interiorly as a subhorizontal, diaphragm-like layer. Sides often circumferentially constricted below a zone of dermal layer. Excurrent systems situated either next to each other, stacked obliquely or subvertically. Axial canals emptying into one or more small oscular centres situated either laterally or on convex crest. Radiating canals of each of the oscular systems principally S-shaped, bent concavely upwards, emptying into wall of spongocoel or continuing as axial canal. Numerous small canals parallelling skeletal trabs, bending convexly upwards and outwards from axis of the sponge body towards lateral surface. Associated apopores isolated or forming centres of small superficial, radiating canals. Anthaspidellid skeletal structure.

\section{Description}

\section{Body form}

Hydraspongia erecta sp. nov. is a cylindrical sponge of variable dimensions, measuring $30-60 \mathrm{~mm}$ (average $43 \mathrm{~mm}$ ) across and $50-105 \mathrm{~mm}$ (average $77 \mathrm{~mm}$ ) high, with an average $\mathrm{W} / \mathrm{H}$ ratio of $1: 1.8$. The stalked, obconical base is covered with a wrinkled, dense dermal layer. Sides have a variable number of alternating zones with and without a relatively thin dermal layer, as shown in the holotype (Fig. 8). Usually, the lateral dermal layer is smooth, but at the transition to another sequence it is thick, even overhanging. Zones without dermal layer have numerous small pores.

LMG G863 is a relatively small sponge, $40 \mathrm{~mm}$ wide and $65 \mathrm{~mm}$ high, composed of a stalked base and two distinct, vertically stacked parts. The obconical base, ca $6 \mathrm{~mm}$ high, is covered by a slightly wrinkled, dense dermal layer. A sharp rim marks the transition from the base to a $14 \mathrm{~mm}$ high obconical zone covered by a circumferential dermal layer as well, and a diameter increasing from 24 to $38 \mathrm{~mm}$. The median part is conical, 11 - $18 \mathrm{~mm}$ high, its width decreasing from ca 38 to $31 \mathrm{~mm}$ and showing numerous pores. The transition to the subspherical top is very abrupt. The width increases from 31 to $40 \mathrm{~mm}$. The lower zone of this upper part, ca $20 \mathrm{~mm}$ high, has a relatively regular dermal layer, which is very thick at its

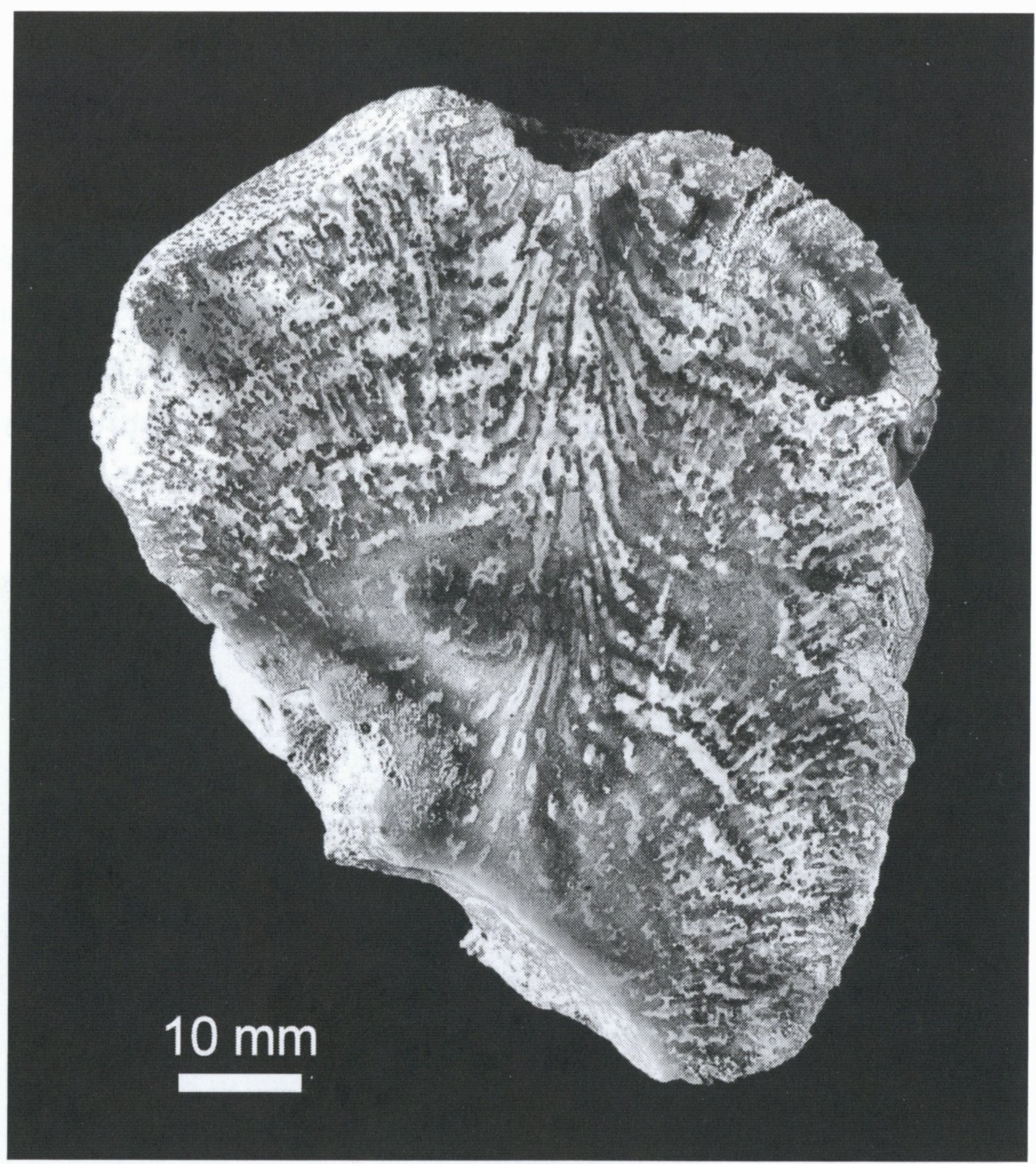

Fig. 9. Hydraspongia erecta gen. et sp. nov. (NME 6300.02115). Paratype. Erratic from Albergen (Twente, the Netherlands). Median view of polished surface. White-coloured contours both of skeletal trabs, diverging upwards and outwards from the axis, as well as of converging S-shaped excurrent canals. Slightly convex canals at the upper right-hand side are part of another oscular system, situated laterally. 


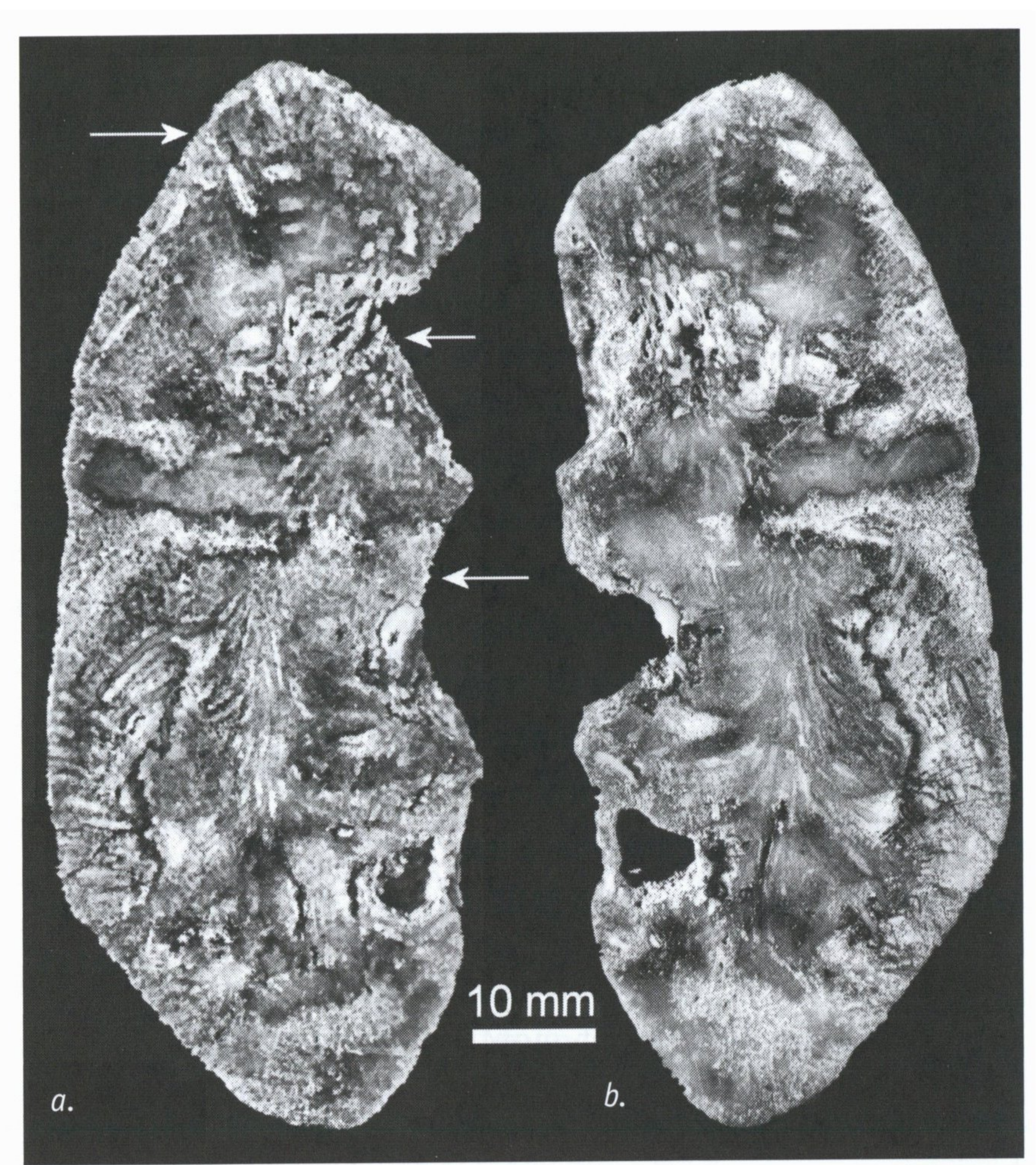

Fig. 10. Hydraspongia erecta gen. et sp. nov. (RGM 211490). Paratype. Erratic from Wilsum (Germany). Median view of polished surfaces. Axial canals in the lower part converge into an oscular centre, which was overgrown during the next growth stage. Canals in the upper part empty into three oscular centres, the lower one overgrown, indicated by arrows. Thus, excurrent systems are stacked (sub-)vertically.

base and with a downward growth. About half the distance between the base and top, at the transition from conical part and dermal rim, some small, superficial canals, ca $4 \mathrm{~mm}$ long and $0.7 \mathrm{~mm}$ across, converge to an undefined centre of some apopores, indicating a poorly developed oscular centre. The regularly convex crest has a central spongocoel, ca $4 \mathrm{~mm}$ across, into which probably 6 - 9 vertical axial canals empty. Somewhat obliquely, there is an obscure second spongocoel on the crest. The sponge body was cut axially, in order to examine the aquiferous system and to confirm a supposed oscular centre in the lower part. Unfortunately, most of the structures were obliterated diagenetically by infill of chalcedony.

Usually, osculi in $H$. erecta sp. nov. are small, especially in relation to the diameter of the sponge. They are $3-6 \mathrm{~mm}$ (average $5 \mathrm{~mm}$ ) across, and $2-8 \mathrm{~mm}$ (average $3 \mathrm{~mm}$ ) deep.

Some specimens developed an oscular centre situated obliquely on the outer wall, as well, usually just below a zone of thick cortex. Other specimens show two, possibly three, excurrent systems stacked subvertically, sometimes separated by a subhorizontal diaphragm-like dense layer as described above. The bundle of axial canals in the upper system may continue into the same direction as that of the former, or decline from the median plane and empty into a spongocoel situated laterally, as seen in NME 6300.02115 (Fig. 9) and RGM 211490 (Fig. 10).
Four additional specimens bifurcated already in an early stage. They developed into a doublet of fused cylinders, each of them with an apical spongocoel, but with a dense, basic dermal layer and circumferential lateral zones of dermal layer in common. Length and height of the sponge body are more or less equal, but the oblong top has a L/W ratio of ca 3:1. Sometimes a small, poorly defined, oscular centre developed laterally, at about half-height.

\section{Canal system}

Remains of the aquiferous system are recognisable in median sections. Usually, skeleton and canals were obliterated by heavy diagenetic silicification, but contours of canals are greyishwhite, different from the otherwise bluish-grey opaque or transluscent chalcedony, as in RGM 211491 (Fig. 11).

Each of the excurrent systems is composed of a bundle of axial canals, emptying into the spongocoel apically or laterally. Radiating excurrent canals are principally S-shaped (Figs 9, 11). Initially, they run convexly upwards and inwards, then change into a more horizontal direction, but near the axis

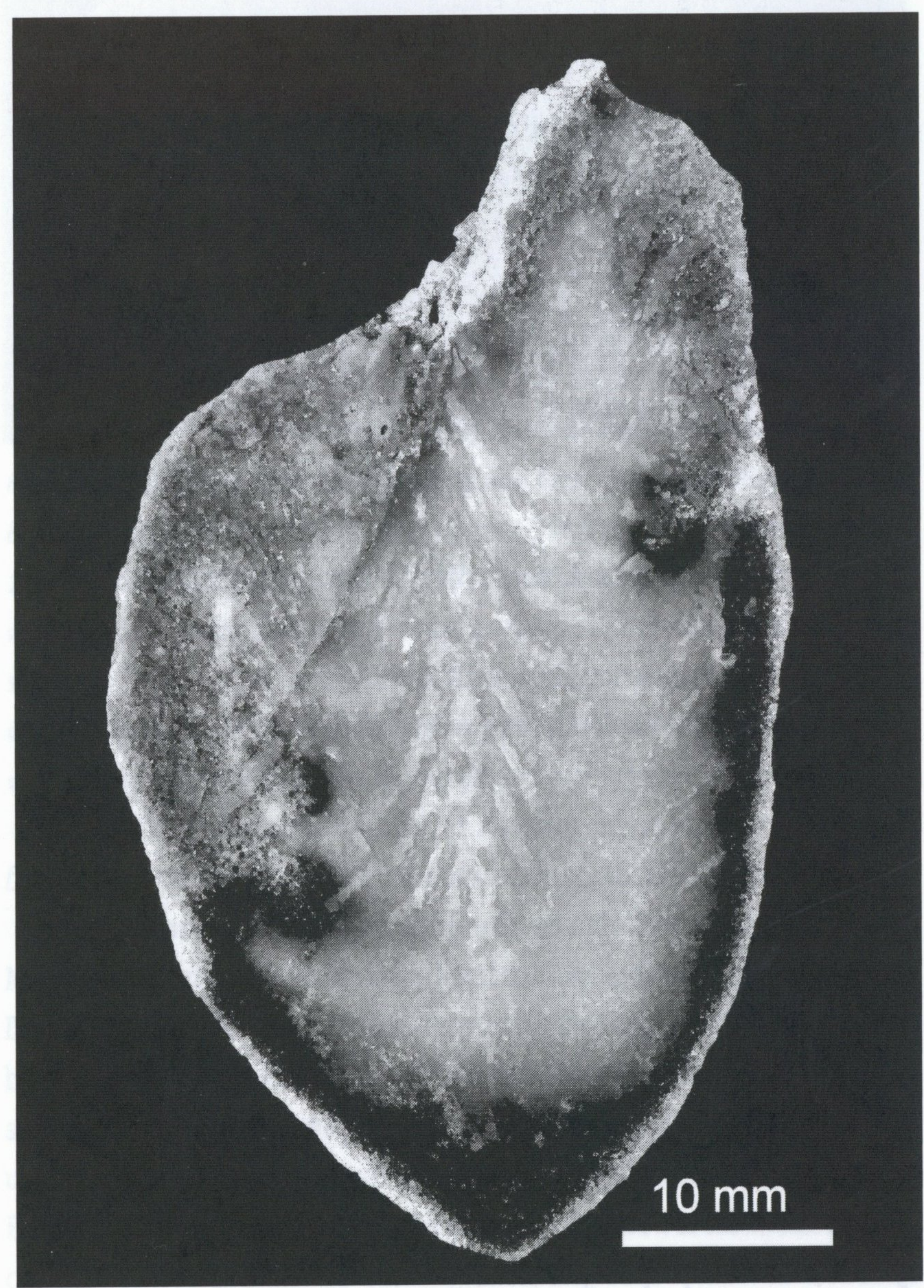

Fig. 11. Hydraspongia erecta gen. et sp. nov. (RGM 211491). Erratic from Braderup, Sylt (Germany). Median view of polished surface. Axial and concavely bent excurrent canals contrast as white contours in greyish chalcedony. The lower distal zone is black by pyritised skeletal parts and contrast with the white, weathered outer surface. Most of the specimens are preserved interiorly as badly as shown here. 
they flare, concavely curved, upwards and inwards towards the axis. There, they merge into the axial canals or, possibly, continue as axial canals. In some specimens, such as RGM 211491 , only the concave sequences of the canals, running to the axis, are observed (Fig. 11).

\section{Skeleton}

Another canal system is composed of convex canals, radiating upwards and outwards, parallel to the skeletal strands. Some of these are $0.4-0.6 \mathrm{~mm}$ wide and associated apopores, ca 0.5 $\mathrm{mm}$ in diameter, are distributed irregularly over the surface. But most canals are much smaller, and associated pores are on average $0.3 \mathrm{~mm}$ across.

The anthaspidellid skeleton is composed of dendroclones arranged in stacked series of trabs, flaring upwards and outwards from the axis of the sponge body to meet the surface, usually at right angles, but the angle varies between ca $70^{\circ}$ and $140^{\circ}$. Predominant are Y-shaped and H-shaped dendroclones, with zygomes firmly connected. Rarely, intercalated coring monaxons are preserved in pyritised portions of some specimens (LMG G863). Walls of small canals are formed by dendroclones with strongly bent shafts, sometimes in combination with a rhizoclone. The choasomal skeleton is composed predominantly of $\mathrm{X}$-shaped dendroclones with short shafts and elaborately developed zygomes. Here chiastoclones are second in frequency. The pattern of convexly radiating trabs, from the median axis towards the outer wall, is continuous and independent of important changes in the aquiferous systems.

\section{Discussion}

Hydraspongia erecta sp. nov. differs from $H$. polycephala sp. nov. in its cylindrical body form, its small osculi and the absence of bulbous oscular centres.

Aulocopium aurantium has some features in common with $H$. erecta $\mathrm{sp}$. nov., such as a thick, irregularly wrinkled basal dermal layer. Irregular growth is often reflected both in body shape and irregular dermal zones usually confined to the lower parts. (For more details see the discussion of the genus above).

Two more species, occurring in the same assemblages as discussed herein, are to be compared with $H$. erecta sp. nov. as well. One of these is Aulocopium cylindraceum Roemer, 1861, which is a slender, stalked, obconical or turbinate species with a zone of dermal layer confined to the base. This species differs from $H$. erecta sp. nov. in its body shape, its excurrent system, and deep spongocoel. A lateral dermal layer, if present, is confined to the basal stalk.

The other of these, Hudsonospongia cyclostoma Raymond \& Okulitch, 1940, is a turbinate to obconical species of moderate size with a central spongocoel, generally without or with a poorly developed basal dermal layer. S-shaped excurrent canals run subhorizontally to the centre, converging at acute angles with the vertical canals. Hydraspongia erecta sp. nov. differs from Hudsonospongia by its cylindrical body shape, its smaller, shorter excurrent canals, its often compound growth and in the presence of extensive zones with dermal layers.

\section{Hydraspongia sp.}

Figure 12.

\section{Material}

NME 6300.02546 (Kamphuis Collection) is an erratic from a sandpit near Wilsum (Germany). It has been previously figured by Rhebergen et al. (2001, p. 63, pl. 5, fig. 3). Seven additional similar specimens known to date are in private collections.

\section{Description}

The taxonomic position of eight nearly identical specimens collected from the WWW-area and Sylt, cannot be resolved at present. One of them, NME 6300.02546, is of sub-spherical shape, and measuring about $40-60 \mathrm{~mm}$ across (Fig. 12). The stalked base is covered by a dense, generally wrinkled dermal layer, which also covers the lower part of the rounded sides, extending upwards to the maximum diameter. Usually, the lateral layer is thinner and smoother than the basal one. The upper lateral part shows numerous circular pores. The regularly convex, hemispherical upper part shows two growth stages. Small, superficial canals run over the initial spherical upper part, converging to an apical spongocoel, which is hidden through overgrowth of a secondarily formed oscular head. The latter covers the former as a rounded, $3-6 \mathrm{~mm}$ thick cap. Usually, the latter is situated obliquely with respect to the former and separated distinctly from it by a zone of dermal

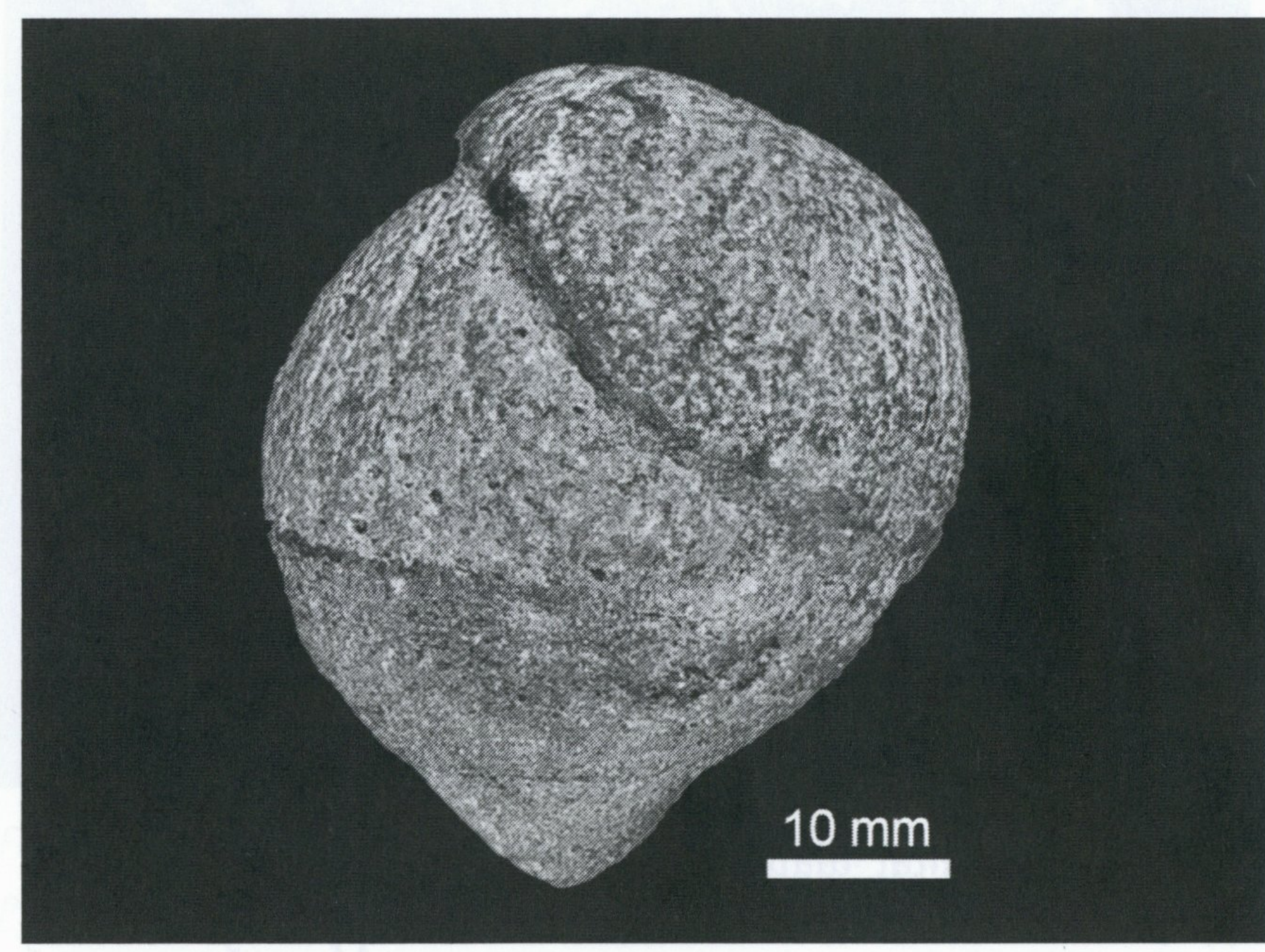

Fig. 12. Hydraspongia sp. (NME 6300.02546). Erratic from Wilsum (Germany). It shows a newly formed head which grew obliquely upon an older one. Note that the upper head developed as a kind of cap only, comparable to the specimen in Fig. 5. 
layer. Converging superficial canals of the latter head empty into an associated spongocoel, which is situated obliquely with respect to the overgrown one. This spongocoel, into which both vertical and radiating canals empty, is $3-6 \mathrm{~mm}$ across and 2 - $3 \mathrm{~mm}$ deep.

\section{Discussion}

These specimens have some features in common with Hydraspongia, e.g. successive formed oscular heads, each with a small spongocoel, and a highly raised dermal layer. On the other hand, they differ considerably, from both $H$. polycephala and $H$. erecta, and may represent yet another species of the new genus, or should be regarded as immature forms of $H$. polycephala.

Hydraspongia sp. has the stalked base with wrinkled, basic dermal layer in common with small, subspherical specimens of Aulocopium aurantium, but differs from that species by hvinga cap-like overgrowth of the top and the highly raised lateral dermal layer. As yet, an assignment in open nomenclature to Hydraspongia gen. nov. is preferred.

\section{Genus Perissocoelia Rigby \& Webby, 1988}

\section{Type species}

Perissocoelia habra Rigby \& Webby, 1988.

\section{Perissocoelia megahabra sp. nov.}

Figures $13-15$.

\section{Etymology}

$\mu \dot{\epsilon} \gamma \alpha \mathcal{S}_{S}($ Greek) $=$ large, referring to the large dimensions of sponge body and oscular centres, compared to the smaller $P$. habra.

\section{Type material}

\section{Holotype}

EZ Z.46061 (Drent Collection). Erratic from a sandpit near Westerhaar (the Netherlands). Coordinates: N $52^{\circ} 33^{\prime} ;$ E $6^{\circ} 53^{\prime}$.

\section{Paratypes}

NRM Sp4587 (Leipnitz Collection), erratic from Lickershamn, Gotland (Sweden), LMG G865, erratic from unknown locality on Gotland (Sweden).

\section{Other material}

Nine erratic specimens, those from Gotland (Sweden) in the NRM, those from Wilsum (Germany) and Sibculo/Westerhaar (the Netherlands) in the NME and in private collections.



Fig. 13. Perissocoelia megahabra sp. nov. Holotype (EZ Z.46061). Erratic from Westerhaar (the Netherlands), indicated with arrow in Fig. 1; a. Top view of the convex crest, showing five of the oscular centres, as well as the general shape of the sponge body. Oscular pits are relatively small, in comparison to those of $\boldsymbol{H}$. polycephala sp. nov., but large, when compared to those of $\boldsymbol{P}$. habra; $b$. Oblique view of flattened base with dense dermal layer. The specimen was cut axially.

\section{Diagnosis}

Massive, obconical or hemispherical sponge of moderate size. Dense dermal layer confined to slightly stalked or flattened base. Several conical oscular centres on regularly convex or slightly undulating crest. Subtangential radiating canals mark upper surface and occur in interior as short radiating canals. Base of each oscular pit marked by cluster of vertical excurrent canals. Smaller, radially arranged canals run from the base of the sponge to the surface, parallel to the skeletal trabs. Anthaspidellid skeleton composed of stacked, ladder-like series of dendroclones, flaring upwards and outwards from radiante near base. Skeleton composed principally of dendroclones and chiastoclones, but rhizoclones occur throughout. 


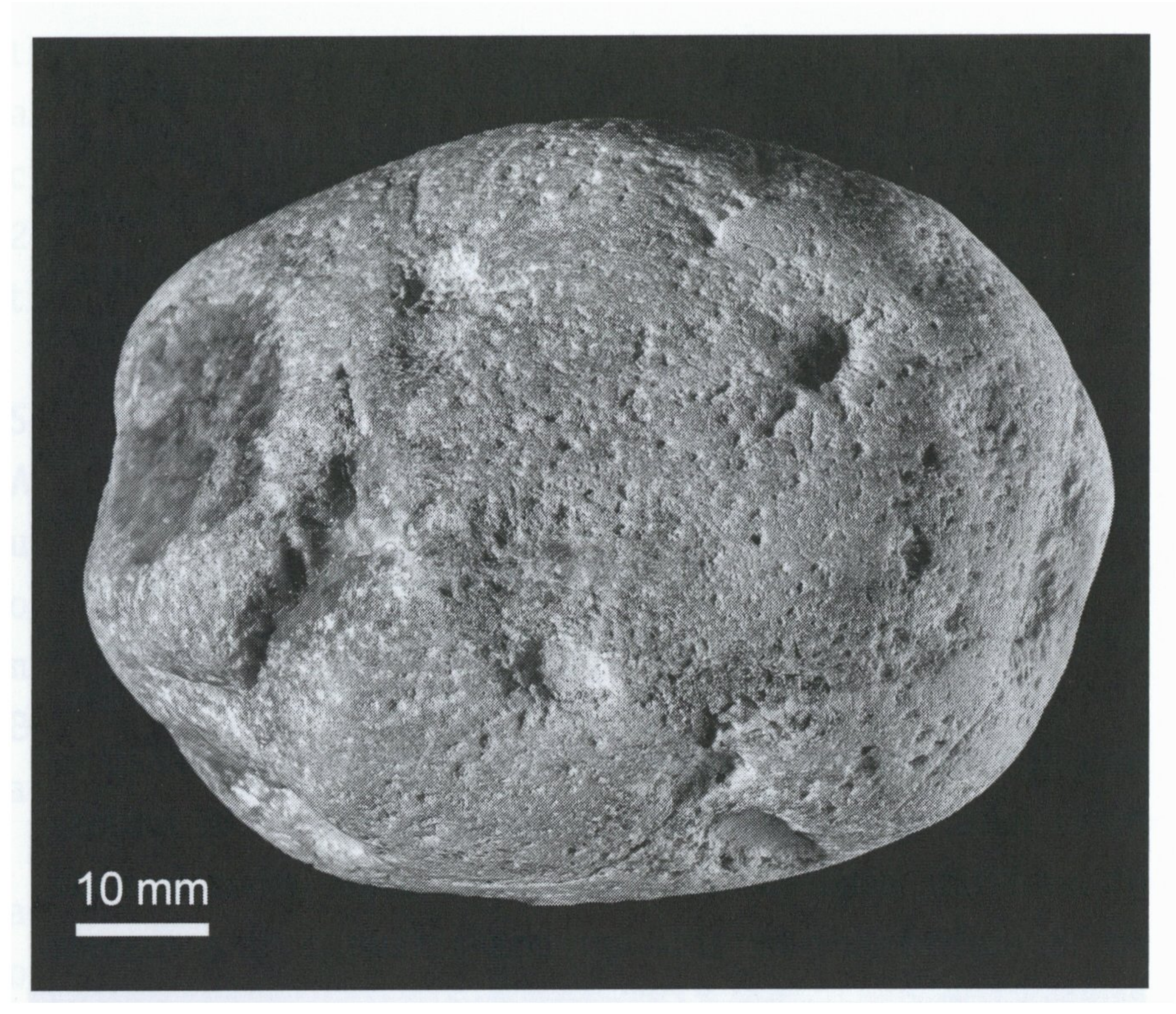

Fig. 14. Perissocoelia megahabra sp. nov. Paratype (NRM Sp4587). Erratic from Lickershamn, Gotland (Sweden). Top view, showing the distribution of oscular centres on top and sides. Note the absence of bulbous heads as in H. polycephala.

\section{Description}

\section{Body form}

The holotype is $77 \mathrm{~mm}$ long, $57 \mathrm{~mm}$ wide and $58 \mathrm{~mm}$ high; it was cut axially. The basal part is slightly stalked, approximately $16 \mathrm{~mm}$ high, with a well-developed dense dermal layer (Fig. 13b). The transition from the base to the upper part is sharp, varying from $70^{\circ}$ to $90^{\circ}$. The convex upper part is eroded, but nine oscular centres are recognisable (Fig. 13a). A small part of the initially steeper top is missing, indicated by a spot of dense chalcedony without any skeletal structure preserved. The distance between oscular centres averages $22 \mathrm{~mm}$. Numerous pores mark the surface.

\section{Canal system}

Most striking are the oscular pits, each of which is the centre of a number of converging canals (Figs 13, 14). The osculi are distributed over the entire surface, except in the basal part, each with a conical spongocoel, into the base of which $6-12$ vertical canals empty. These canals average $0.6 \mathrm{~mm}$ wide, are subprismatic in cross section, and surrounded by stacked series of converging S-shaped canals, rising from below, concavely bent and emptying at acute angles into the spongocoel. Canals in the upper part of the spongocoel run parallel to the surface, emptying normal or at obtuse angles into the spongocoel (Fig. 15).

Canals of a second series are smaller and circular in cross section ( $0.3-0.5 \mathrm{~mm}$ across). They radiate, parallel to the skeletal trabs, from the radiante at the base and from the median axis outwards and upwards to the surface of the sponge, meeting the surface at approximately right angles.

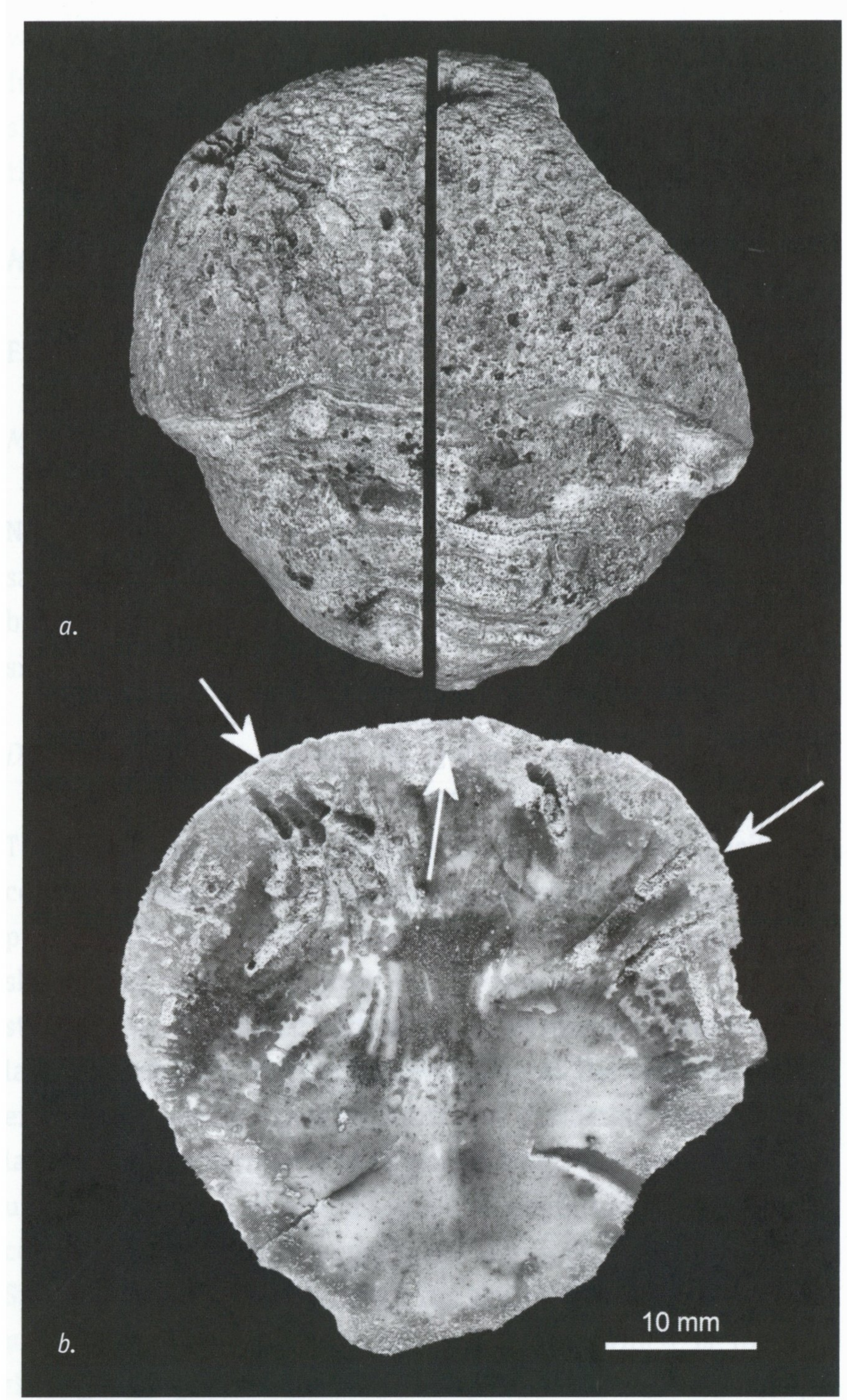

Fig. 15. Perissocoelia megahabra sp. nov. Paratype (LMG G865). Erratic from unknown locality on Gotland (Sweden); a. Oblique view of crest and side. Three oscular systems mark the convex crest. In the broken part a fourth system can be recognised. Dermal zone is confined to the base; b. Median view of polished surface. Some excurrent canals, seen as white contours, converge to an oscular centre in the upper left, other canals run towards an oscular centre in the upper right.

\section{Skeleton}

The skeletal structure is preserved in superficial, partly weathered canals of the holotype. Other specimens, such as NRM Sp4587 (Fig. 14), are silicified to such an extent that skeletal details have been obliterated. The anthaspidellid skeleton is composed predominantly of dendroclones and, to a lesser extent, of chiastoclones.

\section{Discussion}

Perissocoelia megahabra sp. nov. differs from $P$. habra in its larger size. The smallest specimen of $P$. megahabra sp. nov. is larger than the largest known specimen of $P$. habra. The number of oscular pits in $P$. megahabra sp. nov., in relation to 
the surface area of the sponge body, is considerably lower than that of $P$. habra. The holotype of $P$. megahabra has seven oscular pits per $70 \mathrm{~cm}^{2}, 16$ - 58 (mean 33) mm apart. The largest specimen of $P$. habra has nine pits, $10-18 \mathrm{~mm}$ apart. Rigby and Webby (1988, p. 33) recorded a small specimen of P. habra with nine pits per $1 \mathrm{~cm}^{2}$.

Hydraspongia polycephala and $H$. erecta differ from $P$. megahabra sp. nov. in having bulbous oscular centres and repetitive growth stages. $P$. megahabra sp. nov. has a more regular, continuous growth with an increasing number of oscular centres, and a dermal zone confined to the base.

Perissocoelia (?) spinosa is essentially distinguished by its skeletal structure, part of which is composed of didymoclonelike dendroclones (see above).

Perissocoelia (?) gelasinina has a very irregular skeleton with short, discontinuous trabs. In addition, it has numerous small dimple-like oscular pits on the crest, without astrorhizalike radial-tangential canals, and without vertical canals in the base of the pits, and thus, it is different from P. megahabra sp. nov. (see above).

Multistella porosa Finks, 1960 is a Permian compound, subhemispherical species with a layered growth form, and overlapping former layers, comparable to stromatoporoids. The surface has small, astrorhize-like oscular centres, only $1-2 \mathrm{~mm}$ deep, into which small superficial canals empty.

Multispongia aspera Carrera, 2006 is a compound lamellarshaped species from Lower Ordovician deposits in the Argentine Precordillera. Coalescent interconnected spongocoels form a thick, bulbous, laminated body. Associated spongocoels are deep, reaching almost to the base of the sponge. Its skeletal structure is composed mainly of trabs, in which vertical fused coring monaxons are the main elements, which are interconnected by I-shaped dendroclones.

\section{Conclusions}

Re-examination of silicified compound sponges from Baltica assigned hitherto to Aulocopium aurantium 0swald, 1847, A. compositum Conwentz, 1905 and Perissocoelia sp. Rigby \& Webbey, 1988, leads to reconsider their taxonomy, and to re-assign most of the material to the new taxa Hydraspongia, including $H$. polycephala and $H$. erecta, and to Perissocoelia megahabra proposed herein.

The oldest orchocladinid compound sponge known to date is Multispongia aspera Carrera, 2006, from the Lower Ordovician Argentine Precordillera. The occurrence of Perissocoelia Rigby \& Webbey, 1988, from the Malongulli Formation of New South Wales (Australia), and from Baltica (Rhebergen et al. 2001) indicates a re-newed development in the Orchocladina during the Late Ordovician. However, growth forms, as decribed in Hydraspongia gen. nov., seem to be restricted to sponges from Baltica, since there are no reports of a similar development in Ordovician sponges from Australia, China, North and South
America. This feature lends a certain identity to the Baltic assemblage and this may be an important fact in considerations on the palaeobiogeographical reconstruction of patterns of distribution.

\section{Acknowledgements}

I am indebted to Sara Eliason (County Museum of Gotland, Visby); Christina Franzén-Bengtson, Jonas Hagström and Javier Herbozo (all Department of Palaeozoology, Swedish Museum of Natural History, Stockholm); Linda Wickström and Lars Karis (Geological Survey of Sweden, Uppsala) and Heilwig Leipnitz, Uelzen (Germany) for unlimited access to collections and generous loan of material. I also thank Gerard Beersma (Ecodrome Park, Zwolle); Franz van Stuivenberg and Marcel Blokhuis (Natuurmuseum Enschede, Enschede), and the private collectors Gerrit Anninga (Schoonebeek); Hans and Ben Kamphuis (Enschede); Tom Koops (Emmen); Bert Metz (Zwiggelte); Harm Snippe (Klazienaveen) for loan of material. I am grateful to Tom Koops (Emmen) and Percy van Keulen (Harderwijk), for worthwhile discussions, as well as to Wynanda Koot, (Free University, Amsterdam) and Gerrit Anninga (Schoonebeek), for cutting and polishing work. I thank Keith Rigby (Brigham Young University, Provo, Utah, USA) and an anonymous reviewer for there contribution, as well as Marcelo Carrera (University of Córdoba, Argentina) for commenting on an earlier draft, and John Jagt (Natuurhistorisch Museum Maastricht, Maastricht) for critical reading and improving the English considerably.

\section{References}

Bergquist, P.R., 1978. Sponges. University of California Press (Berkeley \& Los Angeles): $268 \mathrm{pp}$.

Bijlsma, S., 1981. Fluvial sedimentation from the Fennoscandian area into the northwest European Basin during the Late Cenozoic. Geologie \& Mijnbouw 60: $337-345$.

Carrera, M.G., 2006. The genus Multispongia (Porifera) in the Early Ordovician limestones of the Argentine Precordillera. Ameghiniana 43: 493-498.

Carrera, M.G. \& Rigby, J.K., 1999. Biogeography of Ordovician sponges. Journal of Paleontology 73: 26-37.

Carrera, M.G. \& Rigby, J.K., 2004. Sponges. In: Webby, B. D., Paris, F., Droser, M.L. \& Percival, I.G. (eds): The Great Ordovician Biodiversification Event. Columbia University Press (New York), 102-111.

Conwentz, H., 1905. Das Westpreussische Provinzial-Museum 1880 - 1905. Nebst bildlichen Darstellungen aus Westpreussens Natur und vorgeschichtlicher Kunst. Westpreussisches Provinzial-Museum (Danzig): 54 pp., 80 pls.

De Freytas, T.A., 1991. Ludlow (Silurian) lithistid and hexactinellid sponges, Cape Phillips Formation, Canadian Arctic. Canadian Journal of Earth Sciences 28: 2042-2061.

Eliason, S., 2000. Sunstones and Catskulls. Guide to the fossils and geology of Gotland. Länsmuseet på Gotland (Visby): 166 pp. 
Finks, R.M., 1960. Late Paleozoic sponge faunas of the Texas region: the siliceous sponges. American Museum of Natural History Bulletin 120: 1-160.

Gerth, H., 1927. Die Spongien aus dem Perm von Timor. Jaarboek van het Mijnwezen in Nederlands Indië, Verhandelingen 1926 (1): iv + 99-132.

Hartman, W.D. \& Reiswig, H., 1973. The individuality of sponges. In: R.S. Boardman, A.H. Cheetham \& W.A. Oliver, Jr. (eds): Animal colonies. Development and function through time. Dowden, Hutchingson and Ross (Stroudsburg, Pennsylvania): 567-584.

Johns, R.A., 1994. Ordovician lithistid sponges of the Great Basin. Nevada Bureau of Mines and Geology, NBMG 0pen-file Report 94-1: 1-199.

Krul, H., 1954. Zwerfsteenfossielen van Twente. Nederlandse Geologische Vereniging (Zutphen): 125 pp.

Mehl-Janussen, D., 1999. Die frühe Evolution der Porifera. Phylogenie und Evolutionsökologie der Poriferen im Paläozoikum mit Schwerpunkt der desmentragenden Demospongiae ('Lithistide'). Münchner geowissenschaftliche Abhandlungen. A. Geologie und Paläontologie, 37: 1-72.

Miller, S.A., 1889. Class Porifera. In: North American Geology and Palaeontology. Published by the author (Cincinnati): 152-167.

Oswald, F., 1847. Ueber die Petrefacten von Sadewitz. Uebersicht der Arbeiten und Veränderungen der Schlesischen Gesellschaft für vaterländische Kultur im Jahre 1846 (Breslau): 56-65.

Overeem, I., Weltje, G.J., Bishop-Kay, C. \& Kroonenberg, S.B., 2001. The Late Cenozoic Eridanos delta system in the southern North Sea Basin: a climate signal in sediment supply? Basin Research 13: 293-312.

Pisera, A., 2002. †Fossil 'Lithistids': an overview. In: Hooper, J.N.A. \& Van Soest, R.W.M. (eds): Systema Porifera: A guide to the classification of sponges. Kluwer Academic/Plenum Publishers (New York): 388-402.

Rauff, H., 1893-1894. Palaeospongiologie. Erster oder allgemeiner Theil und Zweiter Theil, erste Hälfte. Palaeontographica 40, 1-346; 41: 347-395.

Raymond, P.E. \& Okulitch, V.J., 1940. Some Chazyan sponges. Bulletin of the Museum of Comparative Zoology at Harvard College 86: 197-214.

Reid, R.E.H., 2003. Class Demospongia: General morphology and classification. In: Kaesler, R.L. (ed.): Treatise on Invertebrate Paleontology, Part E, Porifera revised, 2. Geological Society of America and University of Kansas (Boulder, Colorado and Lawrence, Kansas): E15-62.

Rhebergen, F., Eggink, R.G., Koops, T. \& Rhebergen, B., 2001. Ordovicische zwerfsteensponzen. Staringia 9: 1-144.

Rigby, J.K., 2004. Classification. In: Kaesler, R.L. (ed.): Treatise on Invertebrate Paleontology, Part E, Porifera revised, 3. Geological Society of America and University of Kansas (Boulder, Colorado and Lawrence, Kansas): E1-8.

Rigby, J.K. \& Chatterton, B.D.E., 1989. Middle Silurian Ludlovian and Wenlockian sponges from Baillie-Hamilton and Cornwallis Islands, Arctic Canada. Geological Survey of Canada, Bulletin 391: 1-37.

Rigby, J.K. \& Webby, B.D., 1988. Late Ordovician sponges from the Malongulli Formation of central New South Wales, Australia. Palaeontographica Americana 56: 1-147.

Roemer, F., 1861. Die fossile Fauna der schlesischen Diluvialgeschiebe von Sadewitz bei 0els in Nieder-Schlesien. R. Nischkowsky (Breslau): xvi +82 .

Schmidt, 0., 1870. Grundzüge einer Spongien-Fauna des atlantischen Gebietes. W. Engelmann (Leipzig): iv +88 pp.

Sollas, W.J., 1875. Sponges. Encyclopedia Britannica, 9th ed. Adam \& Charles Black (Edinburgh): 427-446.
Ulrich E.O. \& Everett, O., 1890. Lower Silurian Sponges. Illinois Geological Survey (Paleontology of Illinois, 2, 5), Bulletin 8: 255-282.

Van Kempen, T.M.G., 1982. Aulocopium compositum Conwentz: Geen misvorming maar een aggregatie. Grondboor en Hamer 36: 79-81.

Van Kempen, T.M.G., 1983. The biology of aulocopiid lower parts (Porifera Lithistida). Journal of Paleontology 57: 363-376.

Von Hacht, U., 1982. Aulocopium compositum Conwentz - Eine Fehlentwicklung? Grondboor en Hamer 36: 24-30.

Von Hacht, U., 1990. Fossile Spongien von Sylt. In: Von Hacht, U. (ed.): Fossilien von Sylt III. Verlag Inge - Maria von Hacht (Hamburg): 103-141.

Von Hacht, U. \& Rhebergen, F., 1997. Ordovizische Geschiebespongien Europas. In: Zwanzig, M. \& Löser, H. (eds): Berliner Beiträge zur Geschiebeforschung. CPress Verlag (Dresden): 51-63.

Wood, R., Zhuravlev, A. \& Debrenne, F., 1992. Functional biology and ecology of Archaeocyatha. Palaios 7: 131-156. 